\title{
The Dead as Living History: On the publication of Die Grabsteine vom jüdischen Friedhof in Würzburg 1147-1346
}

A tombstone fragment bearing the word amen appears on the cover of the book Open Closed Open, that was published toward the end of the life of the Israeli poet Yehuda Amichai. ${ }^{2}$ This tombstone comes from the cemetery of Würzburg, Amichai's birthplace, where close to 1,500 tombstones from the twelfth to the fourteenth centuries, either whole or fragmentary, were found and examined. Their discovery began in 1987, as a consequence of the destruction of an old structure that had formerly served as a monastery, in the Pleich district in the centre of Würzburg. A passerby named Rudolph Erben saw that some of the stones removed from the débris bore Hebrew inscriptions. Erben collected a number of the stones and gave them to David Schuster, who headed the city's Jewish community from the 1950s until his death in 2001. When the nature of the stones and their source became clear, Schuster, together with Professor Karlheinz Müller of the Catholic Theology Department of the University of Würzburg, achieved the intervention of public and academic figures to ensure that the stones would be carefully dismantled from the building and moved to a location where they could in the future be studied. Some of the close to 1,500 stones bearing Hebrew inscriptions taken from the building contain whole tombstone inscriptions, and others are partial tombstones that underwent later cutting for the construction of the building in which they were found, many centuries later. These are not the first Hebrew inscriptions to come to light in Würzburg. In 1965, Zvi Avneri published an article entitled 'Medieval Hebrew Inscriptions', ${ }^{3}$ in which he reported on fifteen tombstones and tombstone fragments that had been discovered before the Second World War, some of which were lost in the Allied bombing of the city close to the end of the War. Together with additional tombstones, that were already known before the war but of which Avneri was unaware, the Hebrew

1 On cemeteries as a source for cultural and historical research, see Elizabeth Valdez del Alamo and Carol Stamatis Pendergast (eds.), Memory and the Medieval Tomb (Aldershot: Ashgate, 2000); Avriel Bar-Levav, 'We Are Where We Are Not: The Cemetery in Jewish Culture', Jewish Studies, 41 (2002), pp. 15^-46*.

2 Yehuda Amichai, Open Closed Open (Hebrew; Tel Aviv: Schocken, 1998).

3 Zvi Avneri, 'Medieval Hebrew Inscriptions', Proceedings of the American Academy for Jewish Research, 33 (1965), pp. 1-34 (Hebrew). 
inscriptions that originated in the Würzburg cemetery currently number more than 1,500. (This number refers to the quantity of stones that were found. Since some of the stones complement each other and are actually part of a single inscription, the number of extant whole and partial inscriptions comes to some 1,450.) Hebrew inscriptions are most likely incorporated in the walls of another structure in the city, but for the present we cannot determine the extent of this material. The 'new' stones that were discovered in 1987 were transferred to the storerooms of the University of Würzburg, and their initial documentation was carried out by Professor Müller and his students. Funded by the German-Israel Foundation for Scientific Research and Development (GIF), preparations for the scientific publication of this discovery began in 1996. Professor Müller was joined in this effort by Professor Simon Schwarzfuchs of Bar-Ilan University and myself, with the participation of Dr Edna Engel of the Jewish National and University Library in Jerusalem for the palaeographic-epigraphic aspects of the research. Since then, each tombstone has been read and interpreted, and the fragments have been pieced together, to provide scholars and the public at large with texts as complete and as comprehensible as possible. This corpus was published, together with a comprehensive introduction, in the winter of 2011-2012.4 In this article I will briefly describe the scope of the discovery, together with a number of representative examples. In Sefer Zekhira (Memorial Book), R. Efrayim of Bonn credits Bishop Siegfried with aiding in the establishment of the cemetery, immediately following the massacres of the Second Crusade. He writes:

The following day, the bishop ordered that all the slaughtered martyrs should be collected in carts, including all substantial remains, thighs and shoulders as well as fingers and toes, and that they were to be purified with sacred oil, and all that could be found of their bodies and limbs, and he gave instructions to bury them in his garden. Afterwards, R. Hizqiyahu the son of Rabbenu Elyaqim and his wife Marat [= Mrs] Yehudit purchased that 'Garden of Eden' from the bishop, and they designated it as a permanent cemetery. 'The generous man is blessed, because he gives' [Prov 22:9]. ${ }^{5}$

The participants in the Second Crusade attacked the Würzburg community on 24 February, 1147, and close to forty of the city's Jews were killed that day. We

4 Karlheinz Müller, Simon Schwarzfuchs, and Avraham (Rami) Reiner, Die Grabsteine vom jüdischen Friedhof in Würzburg aus der Zeit vor dem Schwarzen Tod (Neustadt an der Aisch: Verlagsdruckerei Schmidt, 2011).

5 Efrayim ben Ya'aqov of Bonn, Sefer Zekhirah ('Memorial Book'), in Avraham Meir Habermann, The Persecutions of Germany and France: Memoirs by those from the Generations of the Crusades and a Selection of their Poems (Hebrew; Jerusalem: Sifre Ofir, 1971), pp. 119-20. 
know most of their names from the Memorbuch that was published in $1898 .^{6}$ In contrast to what we would expect on the basis of R. Efrayim's description, none of the extant tombstones can be definitely attributed to any of the victims of the Second Crusade. Furthermore, we do not possess even a single tombstone from the Hebrew year 4907 (roughly corresponding to 1147), in which the cemetery was established, the two earliest tombstones dating from the Hebrew year 4908 (corresponding to 28 August, 1147 - 15 September, 1148). Only some four hundred tombstones (that is, less than a third) bear a date; the other Würzburg stones (some 1,100) are merely tombstone fragments of different sizes, that lack the part of the tombstone recording the year of death. ${ }^{7}$ These fragments might include tombstones from the year of the cemetery's founding, and possibly even those of victims of the Second Crusade, for whom the cemetery was established. It is evident, however, that we do not possess the tombstones of most of those murdered in 1147. It seems that the large number of those murdered in a single day made it impossible for the surviving members of the community to arrange separate burials for all the victims, and a tombstone was not therefore erected for each of them. Another possible explanation for the lack of tombstones for the Second Crusade victims is to be found in the manner in which the tombstones came to us. In order to clarify this possibility, we should describe the last days of the cemetery of medieval Würzburg.

On 21 April, 1349, during the time of the Black Death, the Würzburg community came to an end, when its members burned themselves to death in their homes rather than face the fury of the rioting mob outside. Close to that year, the wall encompassing the new quarters of the city was erected, and its builders took tombstones from the Jewish community's abandoned cemetery as building material. Two centuries later, in 1576, 430 years after the establishment of the cemetery by Bishop Siegfried, his successor at the time, Bishop Julius Echter, appropriated the area of the cemetery in order to build the hospital that bears his name to the present day: the Julius Echter Spital. The stones that remained in the cemetery after the construction of the wall in 1349 were incorporated in the nearby building in 1576, where they were finally found about twenty-five years ago. The discovery of the stones matched their disappearance in its two stages. The wall that had been erected in 1349 was demolished in 1854, and a number of tombstones came to light, and found their way

6 S. Salfeld, Das Martyrologium des Nürnberger Memorbuches (Berlin: Leonhard Simion, 1898), p. 12.

7 The undated inscriptions were dated on palaeographic grounds by Dr Edna Engel of the National Library of Israel, and they appear in our edition in accordance with this dating. 
to the city museum, and to the home of a Würzburg resident. These were the fifteen tombstones listed by Avneri in his article. The second phase was the great discovery of 1987, in the building in the Pleich quarter. While most of the tombstones published by Avneri date to the early fourteenth century, only seven of the 1455 tombstones that came to light in 1987 are from that century, with the decisive majority from the twelfth and thirteenth centuries. The significance of this fact is that stones were taken from different areas of the cemetery at different periods, as they were needed at the time. The fifteen tombstones published by Avneri came to the city wall from the new section of the cemetery, that had been in use in the beginning of the fourteenth century, while the other extant inscriptions came from other parts of the cemetery, which explains the paucity of extant tombstones from that period. In the light of this, any scholar who uses the Würzburg tombstones must realize that the collection, despite its impressive size, paints an incomplete - and even somewhat misleading - picture of the community from its inception to its destruction during the time of the Black Death. We may reasonably assume that if the wall built in 1349 had been dismantled more carefully in 1854, as the other structure was disassembled in 1987, we would possess a more comprehensive knowledge of the community in the first years of the fourteenth century. Likewise, if additional structures in the Pleich quarter were dismantled, including the foundation of a structure that was only partly taken down in 1987, we would undoubtedly have in our possession additional inscriptions that would shed light on the history of the community, mainly in the twelfth and thirteenth centuries.

The argument that the extant collection of tombstones reflects only a proportion of the tombstones in the Würzburg cemetery dating from 1147 to 1349 is supported from another point of view. More than seventy names of individuals who were active in Würzburg during that period are known to us from the rabbinic literature of the time, but we have only about fifteen tombstones of these people. This strengthens the argument that the extant collection of Würzburg tombstones, despite its impressive size, does not represent the entire picture. Possibly, some of the individuals whose names are known from the literature left Würzburg at some point. It is also likely that even if they spent their entire lives in the city, they might have died while travelling or on a visit to another city, and were buried where they died, just as a person from 'the islands of the sea' (= England) died in Würzburg and had a tombstone erected over his grave, and just as tombstones were erected over the graves of a woman from Strasbourg and other visitors who died in Würzburg. ${ }^{8}$ Regardless,

8 The names of the localities mentioned on the Würzburg tombstones, in most instances specifying the place of origin of the deceased, are: Bamberg, France, Frankfurt, Göttingen, Grüns- 
the large quantitative disparity indicates that the extant tombstone collection does not fully document all the members of the community who died in their city.

As regards the quantity of the tombstones, we should also point out another lacuna: the extant collection of tombstones does not include a single tombstone erected over an infant's grave. Only four tombstones describe the deceased as a boy or girl, in contrast to the sixteen that portray the deceased as a na'ar or na'ara (male or female youth, respectively) and more tombstones that depict the deceased as a bahur or bahura (young man or woman, respectively). All this clearly indicates that tombstones were hardly ever raised over the graves of young children, thus revealing the status of children while alive, and even more, after their death. It should be mentioned in this context that, with a single exception, the age of the deceased is not specified on the tombstones; and the birth date is never mentioned. This lack of information prevents us from determining from what age a person was entitled to have a tombstone erected over their grave.

Despite these deficiencies and methodological difficulties, the development of the Würzburg community can be charted by charting the number of tombstones from the time when the cemetery was active along a time axis: between 1147 and 1200: 13 tombstones; 1201-1250: 109 tombstones; 1250-1298: 268 tombstones. 9 Three tombstones date from the end of the Hebrew year 1298, toward the end of which more than 900 members of the community and their guests were murdered in a single day (23 July, 1298) in the Rindfleisch massacres. The names of more than 600 of the victims are known from the Memorbuch mentioned above, but we apparently cannot match any of these three tombstones to the names in the list of the dead. The large number of victims most likely prevented the individual interment of the dead and the erection of tombstones over their graves. We do not have a single tombstone from the time of the massacre in July 1298 until December 1306, while from then until December 1346, the time of the last tombstone in the collection, we possess only nineteen tombstones. The numerical disparity between the years preceding 1298 and those following it indicates that, even if the Würzburg community was finally destroyed only during the time of the Black Death riots in 1349, already by 1298 all that remained in the city were remnants of the community that had once flourished, both demographically and creatively, during the

feld, Halle, Hammelburg, Hassfurt, Möckmühl, Mühlhausen in Thüringen, Nürnberg, Regensburg, Röttingen, Speyer, Tauberbischofsheim, Ulm, Wertheim.

9 These numbers relate only to the tombstones on which dates appear, and not to those dated by palaeographic means. 
course of the thirteenth century - and from that period we possess a few tombstones of individuals that are known to us from various literary sources. ${ }^{10}$

Thus, R. Yișhaq ben Moshe of Vienna was one of the leading authorities of Ashkenaz in the first half of the thirteenth century, and owed his renown to his monumental work Or Zaru'a. In his youth R. Yiṣhaq frequently travelled between different talmudic academies in Europe, and testimonies to his stay in Würzburg, as a teacher and as a student, appear in the contemporary literature. In Würzburg he almost certainly studied under R. Yonathan ben Yișhaqa, ${ }^{11}$ whose widow's tombstone was found in its entirety in Würzburg, bearing the following inscription:

1 'On the full moon

2 of our feast day'

3 died Marat [Mrs] Hanna

4 our mother, the widow of Yonathan

5 Rabbenu [our master], the daughter of R. [an honorific title, not meaning 'Rabbi']

Yehiel our grandfather the kohen [i.e. of the priestly class] the year

6 ma.l.k.o. by the minor count, may her [s]oul

7 be bound up in the bond of everlasting life

The wording ba-kese for our feast day (ll. 1-2)12 refers to Ps 81:4: 'Blow the horn ba-kese for our feast day.' The BabylonianTalmud (Roš. Haš. 8a-b) expounds this verse as relating to the New Year, the only Jewish holiday that begins a month, and on which, therefore, the moon is 'covered' (mekhuse). This woman's death on Rosh Ha-Shana led the writers of the epitaph to use the world malko (literally, 'his king'; 1. 8) to denote the year, in order to allude to God's kingship in the world, a very pronounced motif in the Rosh Ha-Shana liturgy. The woman apparently died on Rosh Ha-Shana, in the year memlamed-khaf-waw (with the numerical value of 96), ie, 5096, that fell on 19-20 September, 1335. A palaeographic analysis, however, along with the location of the tombstone in the Pleich quarter, in which most of the tombstones are from the twelfth and thirteenth centuries, preclude any possibility of dating this tombstone to the fourteenth century. This Hanna most likely died a century earlier, on Rosh Ha-Shana of 4996 (1235). The tombstone writers omitted

10 For the history of the Würzburg community in this period, see Z. Avneri, Germania Judaica II/2 (Tübingen: Mohr, 1968), pp. 928-36; K. Müller, Die Würzburger Judengemeinde im Mittelalter (Würzburg: Freunde Mittelfränkischer Kunst und Geschichte, 2004).

11 On R. Yiṣhạaq's studies in Würzburg with R. Yonathan, see U. Fuchs, 'Studies in the Book Or Zarua by R. Isaac ben Moses of Vienna', (Hebrew; master's dissertation, Hebrew University of Jerusalem, 1993), p. 16.

12 In MT, this word is spelt with a final letter he. The spelling here, with a final alef, is known from midrashim emanating from the Land of Israel. 
the letters denoting the centuries in their desire to denote the year by means of the world malko, which was connected to the day (Rosh Ha-Shana) of her death. Thus, Hanna died on Rosh Ha-Shana 4996, which fell on 15-16 September, 1235.

Who was this Hanna? The tombstones in the Würzburg collection usually relate women only to their fathers, while no mention is made of the husband. Only two tombstones are exceptions to this rule, and in both of them the husband's standing was the reason for the change from the accepted practice. 'Yonathan Rabbenu' was such a husband, to the extent that Hanna's children based their mother's prestige on her marriage to a man who was not their father, for if they were the children of 'Yonathan Rabbenu', they would undoubtedly have mentioned this, and not merely written the title, without indicating their connection with him. 'Yonathan Rabbenu' was the leading sage in Würzburg in the early thirteenth century. He did not leave a distinguished literary legacy, but he was the teacher of many other sages, the most famous of whom was R. Yiṣhaq, the author of Or Zaru'a. The sage's importance motivated the tombstone writers to adorn their mother's memory with the name of one of her husbands, and not that of another of her husbands, who was their father, but lacked the renown of R. Yonathan.

Hanna's prestige came from her husband, while other women's tombstones depict them and their actions, and not only their families. The following is such a tombstone:

1 She left her father

2 [.] in the Rock of Israel

3 [..] dwells in the bosom

4 of our father [Abraha]m, her father, on the day

5 [A]dar, year 10

6 [M]ay her soul rest

7 [.] Amen A[men] Se[lah]

This woman was a convert: like Ruth the Moabite, she left her father and mother (following Ruth 2:11) and came to the Rock of Israel (ie, the God of Israel, following Isa 30:29). The presence of a woman convert in this period in Ashkenaz is in itself of special interest; but the wording chosen by the tombstone writers, who place this convert 'in the bosom' of the patriarch Abraham, is also worthy of our attention. The midrashic work Pesikta de-Rav Kahana ${ }^{13}$ connects this wording with those circumcised: at the time of the circumcision, the one undergoing this act is in the bosom of Abraham, who was the first to

13 Pesikta de Rav Kahana, ed. by B. Mandelbaum (New York: The Jewish Theological Seminary of America, 1987), 1:44. 
undergo circumcision and to circumcise. A different and more charged use appears in the Midrash Lamentations Rabba, in a narrative that portrays the actions of Miriam daughter of Tanhum, whose seven sons died for refusing to bow down before an idol. When Miriam gazed upon her six-year-old seventh son as he was deliberating with the Roman soldiers, she is cited as telling him: 'Let not your courage falter [Deut 20:3]. You are going to your brothers, and you will be in the bosom of Abraham'. ${ }^{14}$ In the consciousness of Miriam (or perhaps that of the author of Lamentations Rabba), the bosom of Abraham is the place where martyrs are expected to arrive. A similar consciousness is indicated in another source from Ashkenaz. The chronicle portraying the massacre in Worms in 1096 quotes a man named Meshullam ben Yiṣhaq who tells his wife, before he slaughters his son: 'I shall not delay for even a moment; the One who gave him to us will take him to his portion, and place him in the bosom of our father Abraham.' 15 Once again, as in Lamentations Rabba, Abraham's bosom is the place that is assured to those who die a martyr's death.

A completely different consciousness emerges from this epitaph. The bosom of Abraham is not promised here to martyrs, but to converts. The connection between converts and Abraham is deeply rooted in rabbinic teachings, since Abraham, as the first convert, is always identified as their father. ${ }^{16}$ The innovation introduced by this epitaph is the use of the wording 'in the bosom', in the bosom of Abraham, as the intended destination of converts in the world to come; such a usage is unprecedented in rabbinic literature and in the literature of early Ashkenaz.

A number of years ago Jérôme Baschet indicated the distribution of the expression 'the bosom of our father Abraham' in Christian literature and art during the eleventh to thirteenth centuries. ${ }^{17}$ He maintained that in the Christian world during that period this verbal and artistic expression symbolized the spiritual bond between Abraham, the ancient father, and those who accepted Christianity, while consciously foregoing their biological paternity, that of the flesh. As in the Jewish tradition, Christian tradition's identification of Abraham as the father of those converting to Christianity throughout the ages is quite distinct, and has ancient roots. Additionally, the phrase 'the bosom of Abraham' already appears in Luke 16:22-4, when the poor man Lazarus, tormented

14 Midrasch Echa Rabbati, ed. S. Buber (Vilna: Romm, 1899), p. 84.

15 E. Haverkamp, (ed.), Hebräische Berichte über die Judenverfolgungen während des Ersten Kreuzzugs (Hannover: Hahnsche Buchhandlung, 2005), p. 285.

16 See, eg, $y$ Bik. 64a (1d).

17 J. Baschet, Le sein du père: Abraham et la paternité dans l'Occident médiéval (Paris: Gallimard, 2000). See also S. Schwarzfuchs, 'Le sein d’Abraham', Revue des études Juives 163 (2004), pp. 283-88. 
and rejected, is said to be in the bosom of Abraham after his death. Towards the beginning of the millennium, however, the expression 'the bosom of Abraham' assumed a new meaning in the Christian conceptual world, and became the place assured to those who accepted Christianity. This consciousness intensified during the course of the twelfth and thirteenth centuries.

The writers of the convert's epitaph did not need to borrow the identity of Abraham as the father of converts, or the expression 'the bosom of Abraham', from the surrounding Christian world, since they could have been quite familiar with them from the internal Jewish tradition. On the other hand, the conception of the bosom of Abraham as the place of the converts in the afterlife almost certainly originated in the Christian environment, in which the notion that this bosom is the proper place for those entering Christianity made its appearance close to this time. This convert's sons accordingly infused the early Hebrew expression with a meaning that came from the Christian cultural field, which they had known before their conversion. The family members therefore acted as 'cultural agents' who, either consciously or unwittingly, transferred language and meaning from their original Christian family to the Jewish community that they had entered and in which they died - the Würzburg community.

The role of converts as cultural agents who bring values from their first world into their new one can also be understood from a responsum by R. Yoel Ha-Levi, who was active in Ashkenaz in the last third of the twelfth and the early thirteenth centuries. The responsum appears in the collection of responsa of his son, R. Eli'ezer ben Yoel Ha-Levi of Bonn:

\begin{abstract}
A spirit came from the Lord and rested in the heart of this person, R. Abraham son of our father Abraham. Now when the spirit rested upon him, he drew near to the Lord's work, to seek the Lord, to study the book [i.e., Torah] and the holy tongue. He dwelt with us for a long time, and he was a blameless and upright man, who stayed inside [see Gen 25:27]. One day I, the undersigned [R. Yoel Ha-Levi, the father of R. Eli'ezer] found him sitting and copying the Pentateuch from an impure book of priests [i.e., a Latin Bible that had been copied by monks or priests]. I said to him: 'What is this in your hand?' He replied: 'I know the language of priests [= Latin], but I do not know the holy tongue [= Hebrew]. Now, this [the Latin Bible] is like an explanation for me, and, what is more, the sages of Speyer lent me priests' books to copy, and they did not try to prevent this. If this seems bad to you, I will cease and not continue.' I responded to him: 'You should know that I find this act to be evil.' He asked me to write on his behalf to my masters in Speyer, who might perhaps permit this to him. I knew that his intent was for Heaven's sake. I acted childishly, and I was impudent to my teachers, perhaps I erred. ${ }^{18}$
\end{abstract}

This convert lived in the second half of the twelfth century, and, as usual for converts in the medieval period, moved between different Jewish communities.

18 Sefer Ravyah, ed. D. Dvelaitsky (Bnei Brak: D. Dvelaitsky, 2005), p. 166. 
The passage indicates that he lived in Cologne, Speyer, and Würzburg. During his stay in Speyer he obtained from the local Jewish scholars books of the Bible in Latin, from which he copied the Pentateuch for himself, so that he could learn something from it. Latin books of the Bible came to Jews as pledges for loans, and their being in the possession of Ashkenazi Jews does not indicate the latter's interest in them. Even if the Jewish sages in Ashkenaz had been interested in the biblical interpretations written in these books, they would have had difficulty in studying them, since they were not sufficiently proficient in Latin. Abraham the convert functioned as an intermediary through whom the members of his new community, the Jews, could become acquainted with the biblical interpretations of Christian scholars. Thus, Abraham the convert may have filled the same role that the converted woman had filled in Würzburg. They and the members of their families served as conduits for the transmission of cultural content; it is unclear whether the Jewish sages of the time were pleased by this transmission.

R. Yoel, whose responsum is cited above, was active for most of his life in Cologne, but his daughter's tombstone is among the collection from Würzburg:

1 In sorrow

2 with stylus incised, in the rock hewn

3 at the head of the dignified woman, Marat Hanna

4 [daughter of] our master, R. Yoel, the grandson of a Kehat [i.e., a Levite]

5 and Momona, the daughter of our master Aban

6 May her soul have repose

7 [b]irth pangs struck her, she died in the month [...]

8 and is gone, it shall be congenial for her soul

9 She shall be deemed among the righteous women

The tombstone of Hanna, daughter of R. Yoel Ha-Levi, who died in the year [5]914 (21 September, 1153 - 8 September 1154), the numerical value of which is expressed in the Hebrew for 'it shall be congenial for my soul', is singular in its size, the attempts at rhyme made in the epitaph, and in that it is the only tombstone that mentions the name of the deceased's mother. Momona, the wife of R. Yoel Ha-Levi, was the daughter of R. Eli'ezer, son of Nathan, 'our master Aban' (known as Raban), the leading Jewish sage in the Rhine communities of the eleventh century. The desire of the epitaph writers to trace the deceased's lineage to her renowned grandfather led them to go beyond the accepted practice in the Würzburg tombstones, both by mentioning the name of the deceased's mother, and by adding the grandfather's name, while normal practice called for mentioning only the father of the deceased. The epitaph, however, is not limited to lineage and her distinguished family. Hanna died when 'birth pangs struck her', thus joining other women on whose 
tombstones this fact was inscribed. The cause of death was generally not mentioned on the Würzburg tombstones, except for women who died during childbirth, or men and women who were murdered by non-Jews, as in the following tombstone:

1 Cherished in their life and in [their] death

2 Never parted, may He wreak their [vengeance]

3 Moshe son of R. Eli'ezer and R. Ya['aqov]

4 son of R. Ele'azar against whom

5 the sons of Esau arose and whom they killed

6 in the month of Elul 403, by the minor count

Two men who were killed by 'the sons of Esau' in the late summer of 1243 are buried under this tombstone. The mention of the cause of their death, and the prayer for vengeance that appears in 1. 3, are not unique. A similar content appears on a tombstone from 1297:

1 This tombstone

2 was erected for

3 R. Moshe who was killed

4 son of R. Avraham die[d]

513 Adar II

657 by the minor count. May there be vengeance

7 by the Lord speed[ily] in [our] days

8 A $[$ men $] A[\mathrm{men}] A[\mathrm{men}] \mathrm{S}[$ elah $]$

These and similar tombstones suffice to reveal that violence, murders, and wishes for vengeance were an integral part of the life of Würzburg's Jews, even in the intervals between the Second Crusade, the Rindfleisch massacres, and the Black Death. And this is not all. These tombstones demonstrate that the Jews of Ashkenaz had no qualms about pleading for divine revenge in a text that was in plain view, in a highly accessible cemetery. Weren't the Jews of Würzburg afraid to carve their request for vengeance in stone, and erect such an inscription in the cemetery? The answer is obviously that they were not deterred from taking such a step, and this in itself is highly instructive. ${ }^{19}$

A second point: this tombstone concludes without the blessing of the 'slain ones'20 to accompany them on their way to the world of the dead; also absent

19 On the centrality in Ashkenaz of the motif of revenge, see I. J. Yuval, Two Nations in Your Womb: Perceptions of Jews and Christians in Late Antiquity and the Middle Ages, Eng. trans. B. Harshav and J. Chipman (Berkeley: University of California Press, 2006), pp. 91-134.

20 'Slain' (ha-neherag) teaches that the deceased died in violent circumstances at the hands of non-Jews. See A. Reiner, “A Tombstone Inscribed”: Titles Used to Describe the Deceased in Tombstones from Würzburg between 1147-1148 and 1346', Tarbiz, 78 (2008), pp. 144-45. 
are 'may his abode be honoured', as well as 'may his honoured abode be in the Garden of Eden', and 'may his soul be bound up in the bond of everlasting life'.21 These and similar blessings were inscribed on all the tombstones found in Würzburg, with the exception of some of those 'slain' by non-Jews, apparently against a background of interreligious hostility. This raises a question. Was a person's murder against the background of such tension sufficient, in the minds of Ashkenaz Jewry, to ensure the victim's place in the Garden of Eden or in the bond of everlasting life, to the extent that the blessings could be waived? An examination of the contemporaneous rabbinic literature teaches that these omissions were not by chance. We read in a responsum by R. Yiṣhaq ben Hayyim, the grandson of the author of Or Zaru'a, who lived in Ashkenaz in the thirteenth century:

The relative of my friend R. Nahman the son of R. Shemarya came to me and showed me a letter from R. Moshe the son of R. Meir, of blessed memory, reporting that our master and teacher, R. Shemarya son of R. Hayyim, ${ }^{22}$ of blessed memory, ordered that the qedoshim were not to be mourned. ${ }^{23}$

The qedoshim (literally, 'holy ones', i.e., martyrs) were those killed by Christians. According to R. Shemarya, mourning practices were not to be observed upon learning of their murder. R. Shemarya's ruling was subject to scathing criticism by R. Yiṣhaq, who wrote: 'I say that atonement and contrition are required for what issued from his mouth.' The wording of R. Yiṣhaq’s reaction indicates the confusion and opposition generated by R. Shemarya's ruling. What is of importance for us, however, is the existence in Ashkenaz at that time of a halakhic determination that those who died a martyr's death were not to be mourned. Echoes of this ruling, and of its distribution, are also to be found in a responsum by R. Ya'aqov Moellin ('Maharil'), ${ }^{24}$ thus demonstrating the way of thinking that regarded martyrdom as such a fit and exonerating death that there was no need to mourn the martyr, nor even to recite the

21 On blessings for the dead on tombstones in Ashkenaz and on the changes they underwent in the medieval period, see A. Reiner, 'From Paradise to the Bonds of Life: Blessings for the Dead on Tombs in Medieval Ashkenaz', Zion, 76 (2011), pp. 5-28.

22 On R. Shemarya, see Naftali Ha-Cohen, Oșar Ha-Gedolim Alufei Ya'aqov (Haifa: Ha-Cohen, 1967-70), vol. 9, p. 54.

23 She'eilot u-Teshuvot Ma-ha-rah Or Zarua', ed. M. Avitan (Jerusalem: Avitan, 2002), para. 14, p. 18. My thanks to Dr Maoz Kahana for drawing my attention to this responsum.

24 Responsa of Rabbi Ya'aqov Moellin-Maharil, ed. Y. Satz (Hebrew; Jerusalem: Mekhon Yerushalayim, 1979), pp. 189-90. This responsum indicates, not only that some sages ruled against mourning, but also that there was such a popular practice: 'I heard from my masters that it happened in the riots in Prague that some desired not to mourn for the martyrs, and, in the end, the leading authorities at the time agreed to mourn.' 
qaddish prayer for his benefit. ${ }^{25}$ The absence of a blessing for the dead on the tombstones of martyrs almost certainly originated in the same mindset. Since they died sanctifying the name of God, there was no longer any need for a blessing to send them on their way, neither on the journey to Paradise nor for their attachment to the bond of everlasting life. The manner of their death ensured them of their place in the world of everlasting life after death. ${ }^{26}$

25 Responsa of Rabbi Ya'aqov Moellin, pp. 189-90: 'I wish to know, my master, what I heard in the name of R. [...] of Tronbork, may the Lord avenge him, who ruled and established that qaddish is not to be recited for one's father who died a martyr's death.'

26 It nonetheless should be emphasized that three additional tombstones that state that the deceased was 'slain' do not contain a wish for vengeance, but do contain a blessing of the dead in the usual forms. Possibly, therefore, the request for revenge contained a degree of daring that was not exhibited by all, and the epitaph writers therefore chose not to write it on the tombstone. This said, however, the appearance of the blessing of the dead on these tombstones should be seen against the background of the halakhic dispute, with its practical implications, briefly mentioned in this article. 
